\title{
Water Injection for Oil Recovery in Mishrif Formation for Amarah Oil Field
}

\author{
Ayat Ahmed jasima, Abdul Aali Al-dabaja and Aqeel S. AL-Adilib \\ ${ }^{a}$ University of Technology/Petroleum Technology Department \\ ${ }^{b}$ University of Technology/Building and Construction Department
}

\begin{abstract}
Water injection, as the secondary oil recovery process, is the most important technology for incremental oil recovery from petroleum reservoirs. Kappa work station software (RUBIS) was used for making the numerical model and history matching. In this research, suggest two cases to enhance pressure and make a comparison in the production of oil and the reservoir pressure for two case studies where the water was not injected in the first case study but adding new vertical wells while other case water is injected. The results of this work represent that if the water is not injected, the reservoir model that has been upgraded and it can produce only $2.9 \%$ of the original oil in place. This case study also represents a drop in reservoir pressure, which was not enough to support oil production. Thus, the implementation of water injection in the second case study of the average reservoir pressure may support, which led to an increase in oil production by up to $5.5 \%$ of the original oil in place. so the case two can be considered the best scenario to develop Mishrif reservoir of Amarah oil field in the next 10 years from (2020-2030) by water injection method through drilling 18 vertical wells in addition to 6 original wells and 8 injection well using inverted nine-spot pattern which has the best recovery factor 5.5\% and keep the pressure (3670 Psia) above bubble pressure (2731 Psia) to producing oil only so that, the use of water injection is a useful way to increase oil production.
\end{abstract}

Keywords: History matching, Amarah, Water injection, Mishrif

Received on 14/10/2019, Accepted on 12/11/2019, published on 30/03/2020

https://doi.org/10.31699/IJCPE.2020.1.6

\section{1- Introduction}

\subsection{History Matching}

History matching is defined as the work of modifying a model of the reservoir so that it almost reproduces the past behavior of a reservoir this is common use in the oil and gas industry so as to make a reasonable future prediction. Reservoir engineers analyze the variation between the simulated and observed value and manually change one or a few parameters at a time in order to improve the match.in such an approach, Reservoir variables are updated manually and oftentimes in two steps: the pressure matching and the saturation matching [1], [2] the nature of this type of data matching, in general, depends on the engineer's experience.

The economic feasibility of a petroleum recovery process is greatly affected by the reservoir production performance under the current and future operating conditions. Therefore the estimation of the past and present reservoir performance and forecast of its future are important in the reservoir management process. During history matching the past performance of the reservoir is simulated and the model is updated in order to match actual historical performance.
The model corresponding to the final date should be supposed to accurately represent the reservoir and be able to predict reservoir performance [3].

\subsection{Water injection}

When the primary oil recovery step produces no more oil, water injection is the most applicable technique to enhance oil production from reservoirs. Not only that also because of the minimum cost of water, as well as the water properties that help sweep the trapped oil efficiently. One of the main problems of this process is the low volume of effective controlling water, especially in heterogeneous reservoirs [4].

When the reservoir pressure is decreased and the rate of oil produced is reduced. Water is injected to enhance pressure, as some production wells are converted into injection wells.

The pressure preservation mechanism in the reservoir is prepared as secondary oil recovery and displays a recovery factor ranging from 20 to $50 \%$, depending on the properties of porous media and the characteristics of liquids. Moreover, water injection is used largely because of the general availability of water, properly water is injected and the ability to propagate water through the formation of loading oil and the effective displacement of oil [5]. 
The minerals suspended in water injection should be minimized to ensure that no rock of the reservoir is clogged, due to the reaction of barium sulfate and strontium in unreacted water with injected water sulfate ions, which increases the volume of barium sulfate and steroid Formation of pipe production and / or connection of reservoir rock around the production well [6]. Oil recovery technology has become an increasingly important problem in fluid management products, including disposal or water production. The development of oil and gas fields takes different types and shapes belong to the conditions and productivity associated with the hydrocarbon reservoir, where planning and management using a different process and advanced technology in implementation at low cost and risk, and therefore implementation depends on financial and human resources technical. Resources with increased investment in capital and employment over time to increase the economic recovery of oil [7].

\subsection{Amarah Oil Field}

Amarah Oil Field is located in Maysan city, about (10 Kilometer) south-west of Amarah city and (10 Kilometer) north-west of Halafaya field and south-east of Kumait field about $(30 \mathrm{Km})$ [8] as seen in Fig. 1. This field lies on the unstable shelf at the Mesopotamian basin. This field currently has 15 wells.

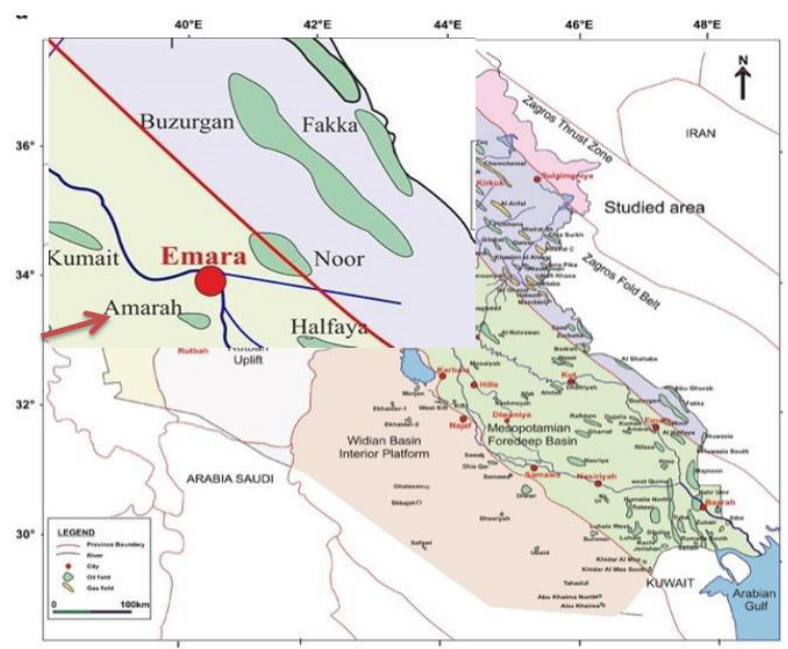

Fig. 1. Location map for Amarah Oil Field [9]

Mishrif formation is an unstable shelf at the Mesopotamian basin is where situated based on Iraq tectonic zones [10] Such setting has an impact on the depositional setting, fracture intensity and structural style. The structure of Mishrif contains a single anticline with axis trending north west-south east. The reservoirs of Mishrif Formation (Cenomanian-early Turonian) in the Oil Field contain compact limestone, chalky limestone, porous limestone and shale with chert at bottom of the Formation. The Lower boundary related to Mishrif Formation represents the change from basinal Rumaila Formation to the shallow open marine facies. It is a conformable surface [11].
Khassib Formation is considered as the upper boundary of Mishrif Formation; such boundary is truncated through unconformity surface which separates the middle from late Cretaceous [12].

The Mishrif Formation can be defined as an overall progradational marine shelf sequence. Following deposition related to transgressive shales and limestones of the Formations of Rumaila and Ahmadi, rudist reefs and additional associated buildups which represent deposition of Mishrif Formation. It Occupies one-third of Iraqi reserves within rudist-bearing stratigraphic units [11]. Late Cenomanian to the Early Turonian has been an age of advantageous conditions around the world for overhead organic productivity has been the main element that controls the location, progress and growth of buildup [13]. The reservoir is composed of two main sedimentary cycles that suddenly ended via unconformity that separate Mishrif Formation from overlying Khassib Formation the Cenomanian-early Turonian [11].

The Mishrif formation has been considered as an essential reservoir and has been divided into seven reservoir units which are MA, MB11, MB12, MB13, MB21, MC1, MC2 and these units separated barriers.

\section{2- Methodology}

1- Collection of the required data such as well logs and core data, this data include porosity, permeability, capillary pressure, and relative permeability.

2- Building 3D geological modeling by using Petrel Software through the volumetric method, first of all, gathering the data related to wells (wellheads and well tops) from fourteen wells then input the map of Mishrif formation and made a polygon. After that imports well $\log$ (porosity and saturation) for distribution through the reservoir also find the oilwater contact finally entered the value of Bo to find oil in place.

3- Inputting the results of the geological model and other data such as fluid properties PVT data and pressure measurements from the final well reports into the software.

4- Building a numerical model by KAPPA work station ( Rubis) software for suggested Mishrif Formation with the intention of representing reservoir performance and obtains oil in place.

5- The production data that gathered from the source (Amarah Oil field will be imported to Rubis software as daily oil production, which we had six wells only producing from Mishrif Formation in Amarah oil field (AM- 1,AM-8,AM-9,AM-11,AM-13and AM14). The first production started in February 2011 from Am-1 until 2018. Also, the pressures reading which we had six reading only will be imported to the software.

6- Making a history matching by comparing the historical field production and the pressures to estimated values

7- Making a development plan, this made by suggestion two cases and made comparison between them: first 
case adding new vertical wells in addition to original six wells to the formation and producing from the main units MA and MB11 while the second case making water injection using an inverted nine-spot pattern.

\section{3- Results and Discussion}

From the geological model in petrel software, the original oil in place was 926MMSTB. After that Kappa workstation software (Rubis) was used to make history matching. The production data for six wells have been entered with porosity, saturation, permeability and compressibility to making a history matching to find oil in place. The history matching was made and the original oil in place was $1025 \mathrm{MMSTB}$ so that the percentage error is low value. The figures below we have been get it from the program about history matching which represents that the dashed brown line shows the pressure match while dark blue line represents the value of pressure while the green line show the production rate values, blue line show water rate and red line show the gas rate vs time Fig. 2 to Fig. 7 show the history match for pressure and oil, water and gas rate for six wells In Fig. 2 and Fig. 4 there is not history match pressure $100 \%$ because maybe there is error in permeability data.while In Fig. 3 in well AM-11 and Fig. 5 we haven't any pressure data. Then in Fig. 6 and Fig. 7, there is a history match pressure $100 \%$.

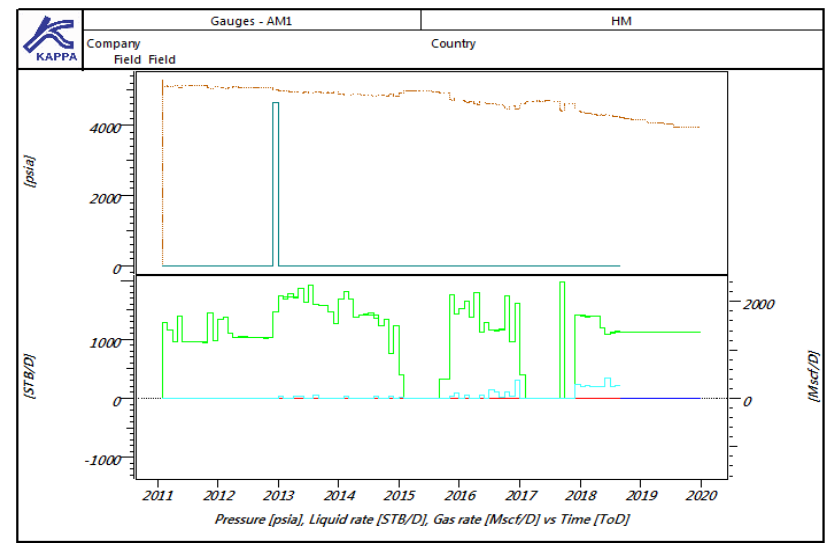

Fig. 2. History match of AM-1

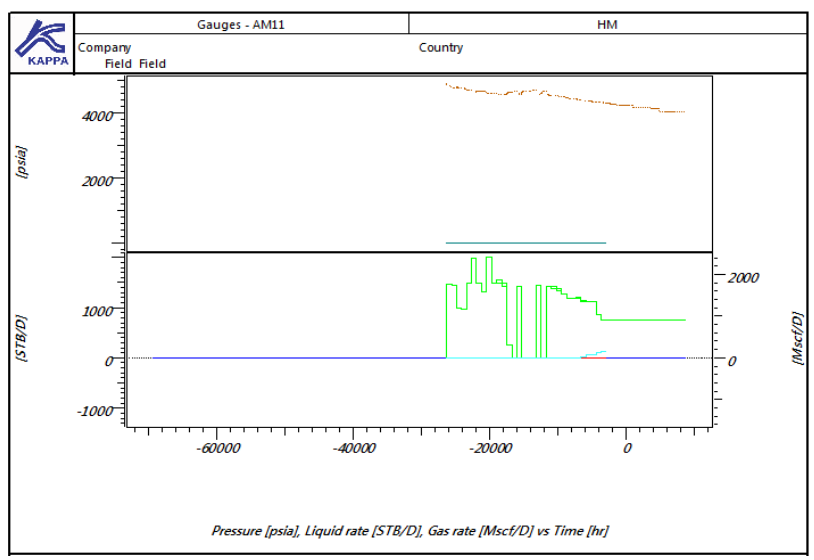

Fig. 3. History match of AM-11

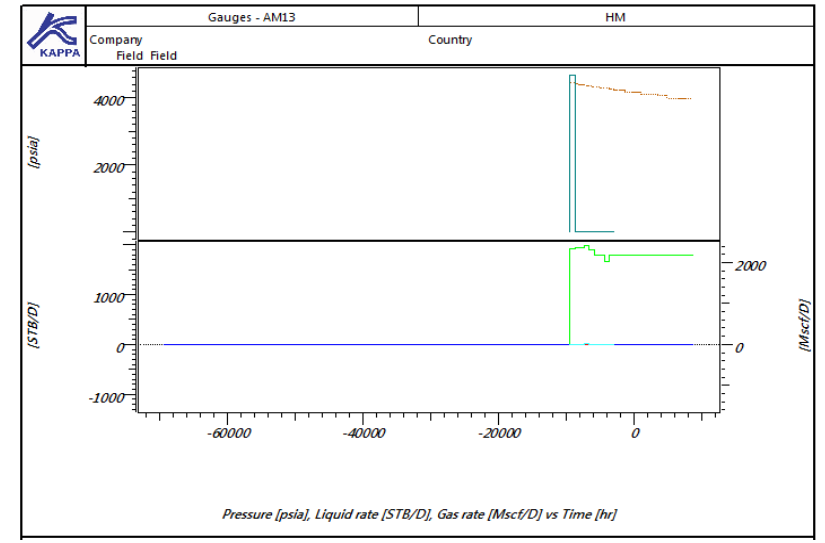

Fig. 4. History match of AM-13

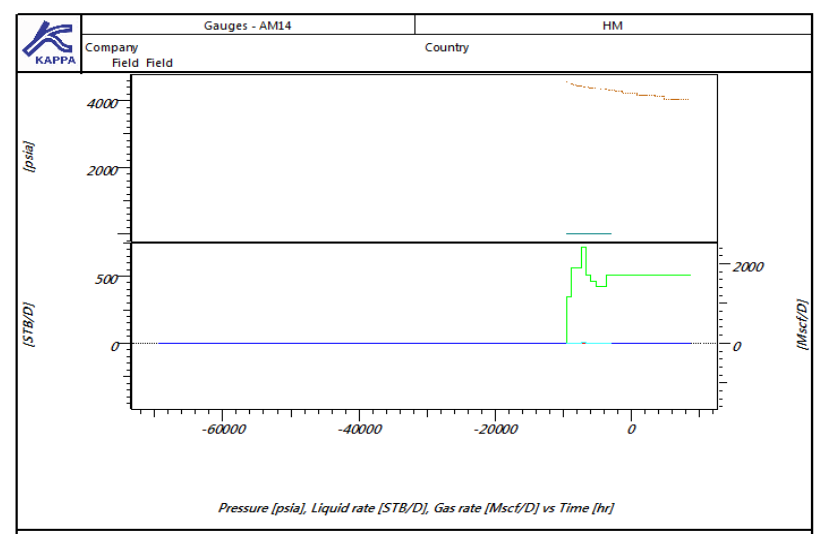

Fig. 5. History match of AM-14

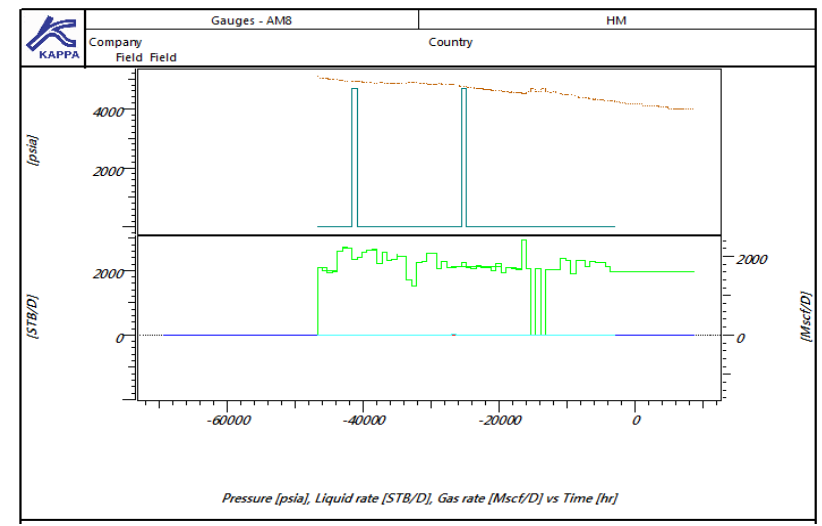

Fig. 6. History match of AM-8

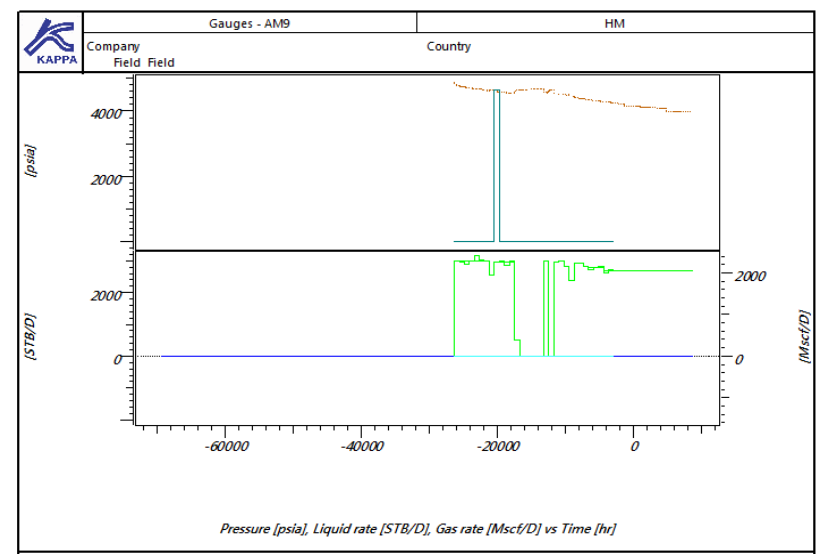

Fig. 7. History match of AM-9 
CASE 1: Adding 26 vertical wells producing from unit MA \& MB11 only:

In this case, drilling 26 new vertical wells instead of horizontal or directional, because the vertical is easy to drill and less cost while horizontal and directional is cost also exhausting the pressure rapidly because producing more than vertical. The wells were suggested which producing from two units MA and MB11, These wells perforated in depth between (9479.528-9810.48)ft from the original well in the map The distance between each well will be $1000 \mathrm{ft}$ as suggested in this research. As displayed in fig. 8, the time for running stated from $(2 / 1 / 2011$ to $31 / 12 / 2030)$, the cumulative production rate of 26 wells and the original 6 wells will be 30303800 STB and the pressure value drop to 3985.75 PSIA and recovery factor is 0.029 at the end of 2030 as displayed in Fig. 9. Calculated by kappa (rubis) software after importing the geological model (porosity, water saturation, permeability) and entering (permeability values, PVT data, production data and pressure) the same procedures well will be adopted for the second case.

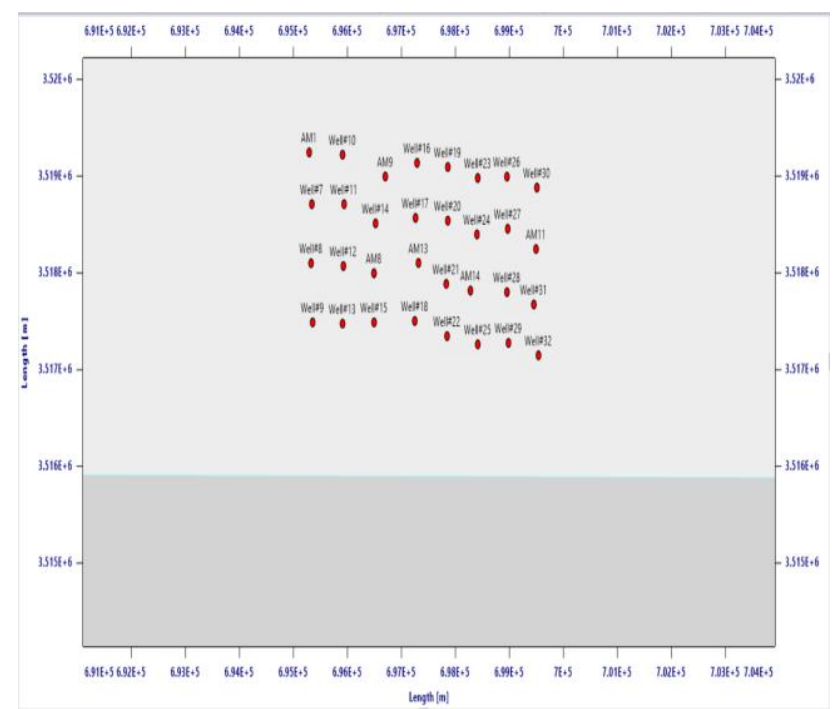

Fig. 8. The distribution of wells in case 1

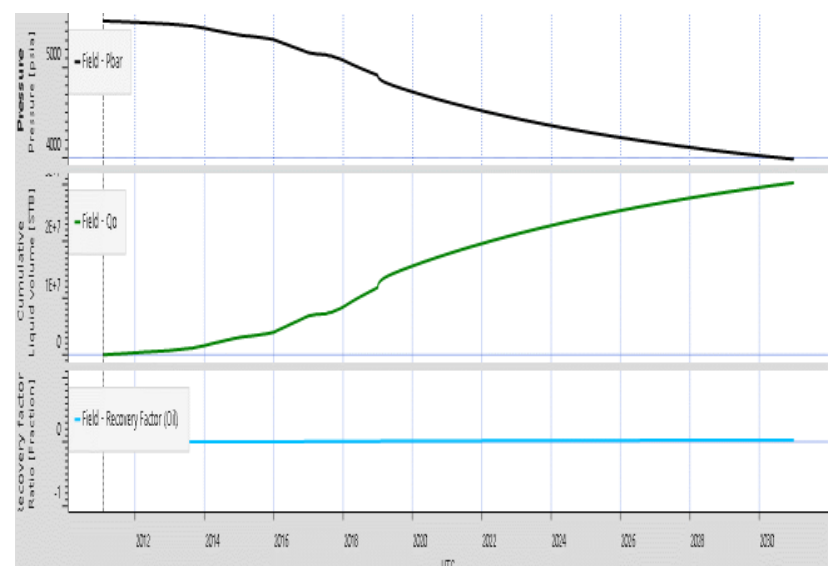

Fig. 9. The Cumulative liquid production, Pressure, Recovery factor vs. Time for case 1
CASE 2: 24 vertical wells production and 8 injection wells:

In this case, water injection was made and will be used inverted nine-spot pattern so the cumulative production rate of 26 wells and the original 6 wells became 57031500.00 STB Fig. 10. , the pressure was dropped to 3670.36 PSIA and the recovery factor was 0.055 as in Fig. 11.

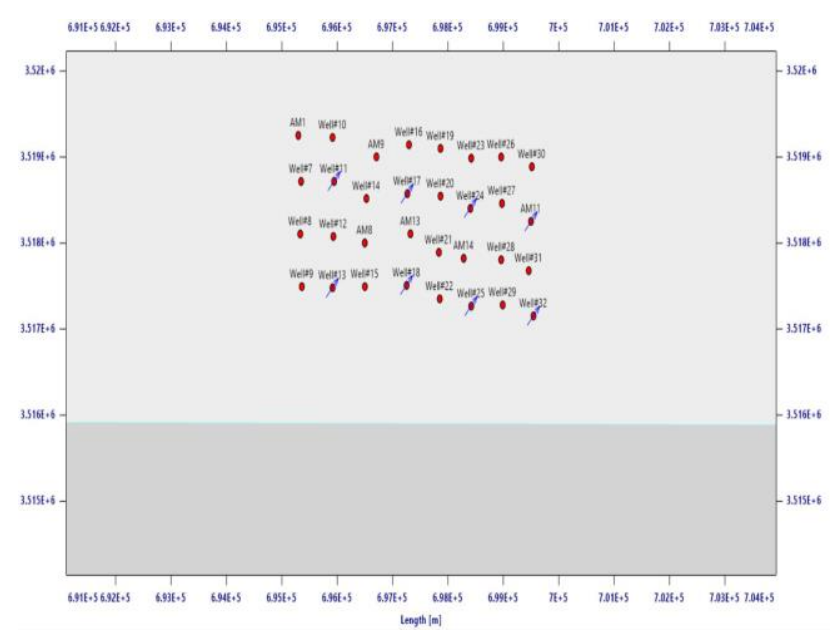

Fig. 10. The distribution of wells in case 2

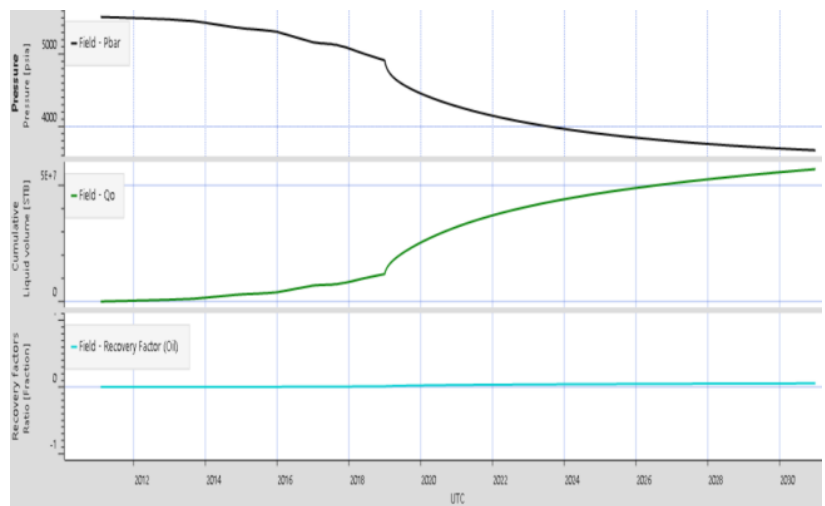

Fig. 11. The Cumulative liquid production, Pressure, Recovery factor vs. Time for case 2

Fig. 12, Fig. 13, Fig. 14 and Fig. 15 represented the two cases as discussed above and show the change in values before and after used water injection. It show that the two cases was important to develop the reservoir but in case one the pressure was dropped to 3985.75 PSIA while the production was little through those years. While case two when we used the water injection method the pressure dropped under the value of case one while the production increased.

Case 2 represents the optimum scenario to develop the field in the future by using the Water injection method through drilling 18 vertical wells in addition to 6 original wells and 8 injection wells which keep the reservoir producing above the saturation pressure for a long time also the water could re-injected. 
The value of pressure started from 5514 psi in 2011 then fall off to 3670 psi in 2030 also the recovery factor was $5.5 \%$ which is controlled in OOIP also It had a water cut $43.3 \%$ because the reservoir is supported by bottom aquifer made the value increased Comparison to case without injection method also average production rate was 8020 STB/D.

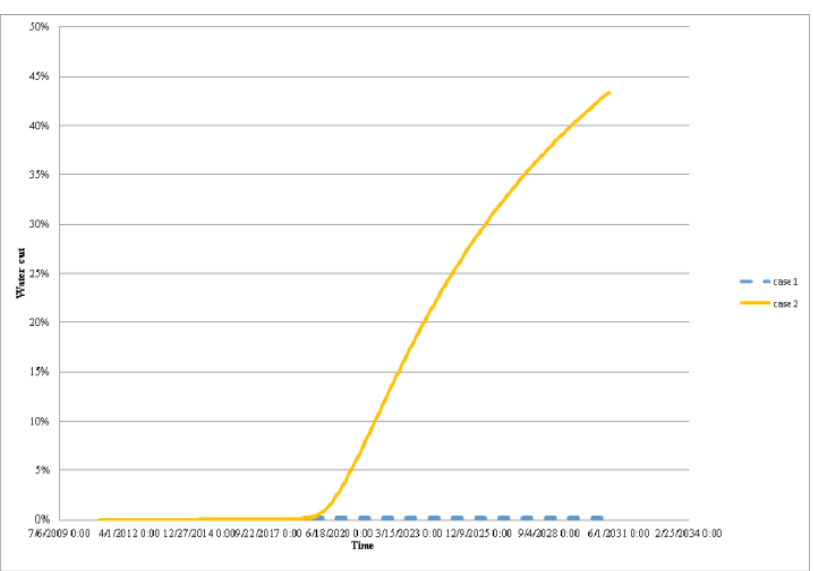

Fig. 12. Water cut vs. Time for two cases

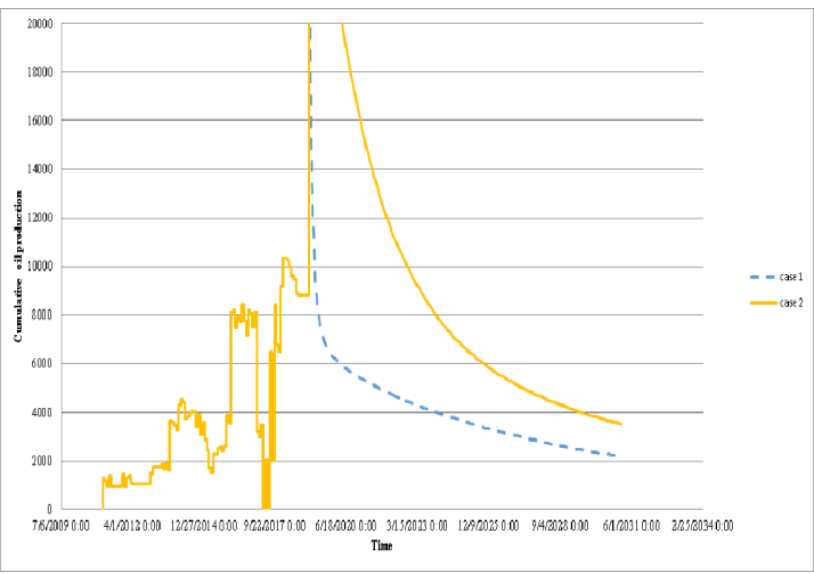

Fig. 13. Cumulative oil production vs. Time for two cases

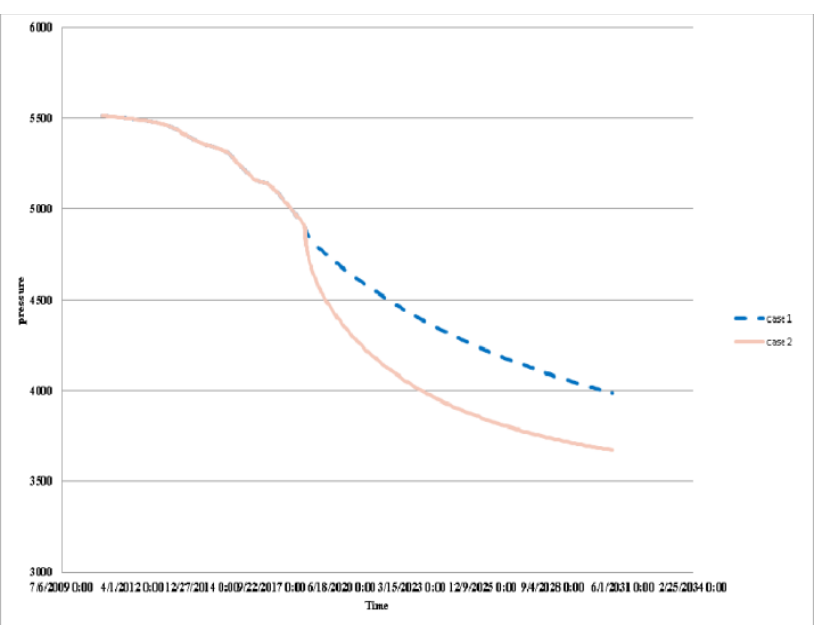

Fig. 14. Presuure vs. Time for two cases

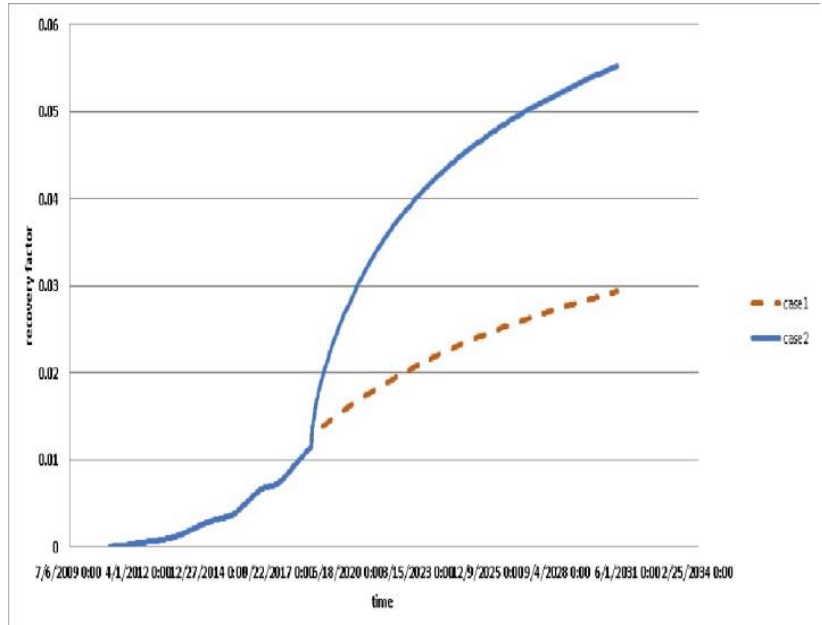

Fig. 15. Recovery factor vs. Time for two cases

\section{4- Conclusion}

1- Water injection technique was used to develop the reservoir because the type of oil was heavy also it easy way rather methods were difficult and need more data and cost.

2- The case two can be considered the best scenario to develop Mishrif reservoir of Amarah oil field in the next 10 years from (2020-2030) by water injection method through drilling 18 vertical wells in addition to 6 original wells and 8 injection well using inverted nine-spot pattern which has the best recovery factor $5.5 \%$ and keep the pressure (3670 Psia) above bubble pressure (2731 Psia) to producing oil only.

3- The development case studies in this research have been important factors for supporting the original driving mechanism in petroleum reservoirs so that the field can continue producing for a long time. In particular, this research has clarified that water injection is one of the most important pressure enhancement techniques for increasing oil production.

4- The drawback of using the water injection method is the expected large production of water which could prevent the oil from being produced. However, the produced water can be useful for re-injection processes which will provide the cost of drilling new water wells and this will also protect the environment from being polluted by the produced reservoir water.

5- In this field, more cases can be a suggestion to increase oil production from the existing oil wells rather than depleting new petroleum reservoirs.

\section{References}

[1] Mattax, C. C. and Dalton, R. L. 1990. Reservoir Simulation, Vol. 13. Richardson, Texas, USA: Monograph Series, SPE.

[2] Saleri, N. G., Toronyi, R. M. and Snyder, D. E. 1992. Data and Data Hierarchy. Journal of Petroleum Technology 44 (12): 1286 - 1293. Paper SPE-21369$\underline{\mathrm{PA}}$. 
[3] Gilman, J. R. and Ozgen, C. 2013. Reservoir Simulation: History Matching and Forecasting. Richardson, Texas, SPE.

[4] A Amiri, AK Manshad "Assessment the Effect of Water Injection on Improving Oil Recovery inX Field."

[5] M Asadollahi "Waterflooding optimization for improved reservoir management." Norwegian University of Science and Technology (NTNU), Department of Petroleum Engineering and Applied Geophysics, Trondheim, Norway (2012).

[6] A. Faiq Al-Alawy and J. Jabbar Madlool, "Coagulation/ Flocculation, Microfiltration and Nanofiltration for Water Treatment of Main Outfall Drain for Injection in Nasiriyah Oil Field", ijcpe, vol. 15, no. 4, pp. 47-66, Dec. 2014.

[7] G. N.Jreou, "Increasing of Oil Field Productivity by Implementation of Re-entry Horizontal Injection Well, Case study", ijcpe, vol. 13, no. 3, pp. 17-34, Sep. 2012.

[8] Khanawi, M.A, Abdul-Ahad, R.J., Sari, J.R., AbdulSaheb, H., Mohamed, A.H., Jaafer, K.H., Salman, S.J., Geological evaluation study for Amara field, Iraqi Oil Explorations Company., 2010.
[9] Al-Ameri, T.K., Al-Jubouri, N.M., Murtadha J. Isa, and Al-Azzawi, R.E., Hydrocarbons generation potential of the Jurassic-Lower Cretaceous Formation, Ajeel Feeld, Iraq. Arab J Geosci Springer pp.37253735, 2013.

[10] VK Sissakian, SFA Fouad "Geological map of Iraq, scale 1: 1000 000, 2012." Iraqi Bulletin of Geology and Mining 11, no. 1 (2015): 9-16.

[11] Aqrawi, A.A.M., T.A. Mahdi, G.H. Sherwani, and A.D. Horbury, Characterization of the MidCretaceous Mishrif Reservoir of the Southern Mesopotamian Basin, Middle East Conference and Exhibition, Manama, Bahrain ,2010.

[12] Jassim, S.Z. and Goof,J.C., Geology of Iraq . Dolin ,Prague and Moravian Museum,Brno (Czech Republic), 341p.2006.

[13] VanBuchem, F.S.P., Razin, P., Homewood, P.W., Oterdoom, W.H., and Philip, J.M., Stratigraphic organization of carbonate ramps and organic-rich intra shelf basins: Natih Formation (middle Cretaceous) of northern Oman. AAPG Bulletin, v.86,pp.21-53, 2002.

\title{
حقن الماء لاستخلاص النفط في تكوين المشرف لحقل العمارة النفطي
}

\author{
ايات احمد جاسم 1, عبدالعال الدباج1 و عقيل العادلي \\ الجامعة التكنولوجية / قسم تكنولوجيا النفط

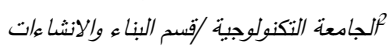

الخلاصة

يعد حقن الماء من أهم التقنيات لتعزيز إنتاج النفط من مكامن النفط. في هذا البحث ، تم تطوير المكمن النفطي باستخدام برنامج KAPPA WORK STATION (RUBIS لمحاكاة المكمن. تم استخدام هذا النموذج لمقارنة إنتاج النفط وضغط المكمن لحالتين حيث تم في الحالة الاولى حفر 18 بئر عمودية بالاضافة الى الابار الرئيسة الموجود بالمكمن ولم يتم حقن الماء لكن في الحالة الثانية نم حقن الماء فأظهرت نتائج هذا العمل أنه إذا لم يتم حقن الماء ، فإن نموذج المكمن المطوّر يمكن أن ينتج 2.9٪ فقط من النفط الأصلي في المكمن. كذلك أظهرت دراسة الحالة هذه أيضًا انخفاضًا في ضغط المكمن الذي لم يكن كافيًا لدعم إنتاج النفط. في الحالة الثانية ، تم تطبيق حقن الماء فقد تم دعم متوسط ضغط المكمن مما أدى إلى زيادة إنتاج النفط ليصل إلى 5.5 ٪ من النفط الأصلي في المكمن. وبالتالي ، فان الحالة الثانية هي الافضل للمحافضة عالمكمن للانتاج لفترة 10 سنوات من 2020 الى 2030 من خلال حفر 18 بئر عمودية و8 ابار حقن والحفاظ على المكمن بضغط 3670 فوق ضغط التشبع 2731 لذلك فإن تطبيق حقن الماء هو تقنية مفيدة لزيادة إنتاج النفط. الكلمات الدالة: النطابق، العمارة، حقن الماء،المشرف 